Дєнєжкін М. М. к.військ.н.,с.н.с.';

Наливайко А. Д. к.т.н., доцент;

Поляєв А. I. ${ }^{2}$

\title{
Особливості оборонного планування у державах-членах НАТО, на основі спроможностей
}

\author{
1 - Центральний науково-дослідний інститут Збройних Сил України, Київ; \\ 2 - Центр воєнно-стратегічних досліджень Національного університету оборони України імені Івана \\ Черняховського, Київ
}

Резюме. В статті аналізуються особливості організації та здійснення оборонного планування на основі спроможностей в державах-членах НАТО. На основі цього аналізу авторами пропонується своє бачення шляхів удосконалення існуючої системи оборонного планування у Збройних Силах України та адаптації його до вимог стандартів НАТО.

Ключові слова: оборонне планування, спроможності, Збройні Сили, стандарти, НАТО.

Постановка наукового завдання. Однією 3 оперативних цілей оборонної реформи в Україні визначено удосконалення системи оборонного планування (ОП) відповідно до євроатлантичних принципів та підходів. На виконання визначених завдань, МO України приступило до нового етапу удосконалення системи оборонного планування, в рамках зазначеної стратегічної цілі № 2, а саме - впровадження планування розвитку спроможностей ЗС України [1]. Для успішного вирішення цього завдання необхідне вивчення досвіду державчленів Альянсу та його урахуванння в новій системі оборонного планування на основі спроможностей 3С України. Це потребує визначення основних етапів оборонного планування в НАТО, зокрема: розуміння процесу розподілу спроможностей НАТО між національними спроможностями державчленів Альянсу, які необхідні для досягнення спільних цілей; організації оборонного планування держав-членів Альянсу та вплив характерних рис національного устрою, прийняті системи планування, ऑii розвиток, умови, в яких здійснюється планування.

Аналіз останніх досліджень, публікацій показує, що проблематика формування майбутнього обрису ЗС України за досвідом держав-членів Альянсу на сьогодні активно досліджується. Вивченню процесу оборонного планування у державахчленів НАТО на основі спроможностей присвячена значна кількість досліджень та документів оборонного планування. Цим питанням цілеспрямовано активно займаються провідні вітчизняні вчені: Горбулін В. П., Шелест С. Ф., Поляков С. Ю., Аскаров В. Х.,
Тимошенко P. I., Денежкін М. М., Лоза I. В., Саганюк Ф. В. та інші.

Але при цьому недостатньо уваги приділялось питанням, пов'язаним з розвитком методу оборонного планування основаному на спроможностях та адаптацією системи оборонного планування 3С України до аналогічних систем країн-членів НАТО. При цьому не враховувались певні відмінності, пов'язані 3 особливостями оборонного планування на основі спроможностей в окремих державах-членах НАТО і Альянсу в цілому та можливостями адаптації системи оборонного планування 3С України до аналогічних систем цих держав.

Метою статті с: аналіз особливостей організації оборонного планування на основі спроможностей в державах-членах НАТО, з'ясування проблемних аспектів існуючої системи оборонного планування 3С України та визначення основних напрямків його удосконалення на основі досвіду державчленів Альянсу.

Викдаденння основнго матеріалу. Удосконалення системи оборонного планування в України (далі - ОП) в напрямку переходу на планування на основі спроможностей та наближення його до прийнятих у НАТО стандартів - $є$ для ЗС України завданнями на найближчу перспективу, що визначено в Концепції розвитку сектора безпеки і оборони України та Стратегії національної безпеки України $[1,2]$.

Також у $[1,3]$ визначається, що в розвитку системи ОП сил оборони, як складової національної системи планування, нагальним $\epsilon$ впровадження в процес ОП сучасних методів, які використовуються 
державами-членами Альянсу для покращення оборонних спроможностей, зокрема, застосування принципу всебічного підходу до оборони, методів планування на основі спроможностей, а також здійснення цілеспрямованої підготовки до виконання завдань за призначенням i матеріальнотехнічне забезпечення потреб оборони держави.

НАТО на сьогодні $€$ найбільшою військовою міжнародною організацією, яка декларує забезпечення безпеки кожної держави, що входить до неї. Забезпечення безпеки базується на принципах, основними 3 яких є [4]: стандартизація та оперативна взаємосумісність 3С державучасниць Альянсу; оптимізація організаційно-штатної структури, бойового та чисельного складу відповідно до умов ведення сучасних війн i збройних конфліктів; прозорість військового

бюджету держав-учасниць тощо.

Реалізація цих принципів

забезпечується, у тому числі, й розвинутою системою оборонного планування на основі спроможностей (далі - ОПОС), яка утворена в Альянсі.

Згідно 3 зазначеними принципами до системи ОПОС у НАТО висуваються вимоги, серед яких найбільш важливими є:

сприяння співпраці і розвитку зв'язків між ними в усіх сферах, в яких забезпечуються їх загальні та індивідуальні інтереси;

спільна відповідальність, а також визнання взаємних обов' язків; HATO;

політична солідарність держав-членів

загальна діяльність із утримання адекватної воєнної сили з метою підтримання стратегії і політики Альянсу.

ОПОС в НАТО здійснюється в інтересах спільного застосування військ (сил). В його основі лежить єдина процедура планування сил як для застосування, так i для розвитку їх спроможностей $[5 ; 6]$.

Важливою метою ОПОС Альянсу $\epsilon$ створення та розвиток військових спроможностей щодо врегулювання кризових ситуацій, як на території НАТО, так і за його межами. Перелік цих спроможностей визначається Стратегічною концепцією оборони і безпеки членів НАТО [7]. Мета ОПОС НАТО визначається на основі вимог стратегічних командувань НАТО та включає
“Цільові завдання з розвитку ЗС НАТО”, які спрямовані на забезпечення можливості вирішувати весь спектр оперативних місій.

У державах Альянсу, для організації ОПОС, прийнята модель, яка грунтується на таких ключових поняттях, як стратегія, кінцеві цілі, сили та засоби, ризик, середовище безпеки та обмеженість ресурсів. У прийнятій моделі відображається динаміка процесу розроблення стратегії національної безпеки та усуваються невідповідності між визначеними в цих державах показниками ОПОС. Як припущення приймається, що процес ОПОС має бути циклічним, 3 перегрупуванням ключових показників, можливістю змінення обраних цілей, удосконалення сил та засобів, перегляду стратегій та періодичного моніторингу величини ступеня ризику, який прогнозується під час розроблення програм та планів.

Процес ОПОС у НАТО включає п'ять основних етапів, які мають, як правило, послідовний та циклічний характер.

Перший eman - визначення засад державної політики у сфері безпеки і оборони. Здійснюється 3 метою формування єдиних для усіх складових сектору безпеки i оборони політичних вказівок. Передбачає розробку (уточнення положень) основоположних документів у сфері національної безпеки і оборони.

Другій eman - визначення потреб (спроможностей). На даному етапі, 3 метою досягнення визначених політичних цілей, на підставі аналізу ризиків та загроз здійснюється розробка ймовірних сценаріїв застосування збройних сил (операцій) та здійснюється формування Єдиного переліку мінімальнонеобхідних спроможностей.

Tретій етап - розподіл спроможностей та визначення завдань. На підставі переліку мінімально-необхідних спроможностей здійснюється розподіл цих спроможностей між країнами НАТО. Формуються Переліки бажаних спроможностей, що мають бути досягнуті (виділені) кожною країною Альянсу та окремо для колективних спроможностей (що досягатимуться за рахунок колективних ресурсів НАТО). 3 метою спрощення процесу імплементації, Переліки бажаних спроможностей можуть бути розбиті на Цільові пакети, що виконуватимуться поступово.

Четвертий eman - імплементація. Основним змістом етапу є виконання завдань визначених Переліками бажаних спроможностей щодо створення (розвитку) спроможностей. Зазначене передбачає розробку (оновлення) настанов (статутів, керівництв), 
закупівлю (модернізацію) ОВТ, підготовку особового складу, проведення навчань, застосування (тестування) та удосконалення спроможностей. Виконання завдань щодо розвитку спроможностей здійснюється шляхом впровадження нормативних документів (стандартів) НАТО.

П’ятий eman - оцінка результатів. Оцінка результатів здійснюється 3 метою визначення ступеня досягнення визначених спроможностей державами-членами НАТО. За результатами проведення оцінки готується Огляд спроможностей та Доповідь про спроможності. На підставі доповіді здійснюється уточнення завдань та коригування планів щодо розвитку (досягнення) спроможностей.

Процес ОПОС застосовується при проведені планування розвитку сил і засобів (спроможностей) на середньострокову та довгострокову перспективи.

Прийнята модель

постійно удосконалюється відповідно до розвитку методологічних засад ОПОС НАТО.

В цілому ОПОС спрямоване на створення та розвиток військових спроможностей, на підготовку до реагування на визначені загрози. Структура ОПОС НАТО у загальному вигляді може бути розглянута, 3 одного боку, як сукупність взаємозалежних процесів та процедур, а саме: оцінювання ВПО, планування сил, планування ресурсів та оцінювання ризиків, які можуть виникнути у майбутньому. 3 іншого боку, як сукупність процесів довго-, середньо- та короткострокового планування, документів, які відпрацьовуються, а також методичного апарату обгрунтування основних положень зазначених документів [5, 6].

При цьому, оцінювання ВПО здійснюється на основі аналізу прогнозованих ризиків та загроз, а також цілей та спроможностей, визначених для державчленів НАТО на заданий період прогнозування і $є$ основою для обгрунтування заходів із планування сил. Планування сил базується на розробленому переліку ситуацій, для реагування на які воно здійснюється.

Аналіз ситуацій для планування та переліку наявних військових спроможностей дозволяє виробити короткострокові та середньострокові вимоги до розвитку складу військ (сил). ОПОС, за допомогою планування Сил, визначає перелік сил, засобів, спроможностей та вимог до структури, необхідних для реагування на найбільш небезпечні обставини.
При цьому під час планування сил визначаються вимоги до спроможностей на наступний період планування. Про результати проведення огляду оборонних спроможностей доповідається Військовому Комітету.

Під час оперативного планування розглядається той же перелік ситуацій, як і для планування сил на предмет ризиків та можливості їх виникнення. Робоча група ОПОС виробляє пріоритетний їх перелік, що у подальшому має бути опрацьований.

Внесок заходів оперативного планування до ОПОС здійснюється під час процесу огляду цілей сил. Оперативне планування визначає перелік вимог до спроможностей сил та засобів, як мінімум, та, бажано, перелік сил та засобів для специфічних ситуацій з планування.

Під час планування сил проводиться узгодження між державами-членами Альянса щодо їх достатності, взаємоузгодженості, взаємосумісності та ефективної взаємодії під час виконання покладених завдань [5-17].

Використання системи планування, програмування, бюджетування, виконання, покладеної в основу ОПОС держав-членів блоку та ЄС, свідчить про взаємозв'язок зазначених процесів [6, 9].

Процеси зв'язані між собою прямими та зворотними зв'язками: довгострокове планування реалізується середньостроковими програмами, основним джерелом виконання яких $\epsilon$ бюджетні асигнування. Зміни запланованих ресурсів автоматично викликають перегляд середньострокових програм, які, у свою чергу, вимагають перегляду довгострокових планів. Зворотній зв'зок визначає коригування попереднього процесу в результаті виконання нижчого. Тим самим забезпечується спадкоємність та залежність видів планування від досягнутих результатів.

Слід зазначити, що НАТО є міжурядовою організацією, держави-члени якої виділяють ресурси, необхідні для забезпечення іiі діяльності. При цьому, переважна більшість 3С i ресурсів держави-членів НАТО, залишається під командуванням і контролем своїх держав.

Члени Альянсу зобов'язуються спільно або окремо надавати війська (сили) та необхідні спроможності, які потребує НАТО для досягнення цілей та виконання поставлених завдань. Процес ОПОС у Альянсі є основним засобом пошуку необхідних спроможностей, своєчасного їх формування та досягнення заданого рівня можливостей (закупівлі).

Прийнято, що високий рівень ефективності ОПОС НАТО $є$ необхідною 
умовою досягнення політичних, військових та ресурсних переваг, яких очікують державичлени від Альянсу. Участю у процесі ОПОС НАТО союзники, без втрат їх національного суверенітету, можуть узгоджувати свої оборонні плани 3 інтересами НАТО 3 метою визначення, досягнення та надання обгрунтованої частки своїх сил та засобів Альянсу для можливості виконання всього діапазону поставлених завдань.

Більшість держав-членів НАТО при здійсненні ОП вирішують не лише завдання визначені потребами Альянсу, а й завдання розвитку власних 3С. Але, у деяких державах 3 невеликою чисельністю 3С, у межах ОП плануються заходи розвитку ЗС, спрямовані лише на визначені потреби НАТО.

Висновки та перспективи подальших досліджень. Таким чином, особливістю ОПОС НАТО є те, що кожна держава Альянсу має свою систему ОПОС, на основний зміст організації та здійснення якого впливають характерні риси економічного устрою; прийнята в державі система прогнозування та система планування іiі розвитку; умови, в яких здійснюється планування; національні традиції тощо. Це вимагає гармонізації (інтегрування) власних національних планів розвитку 3С з планом оборони НАТО.

Перспектива подальших досліджень полягає у аналізі змісту довго-, середньо- та короткострокового оборонного планування на основі спроможностей у державах-членах НАТО та впровадженні отриманого досвіду в перспективній системі оборонного планування ЗС України.

\section{ПЕРЕЛІК ВИКОРИСТАНОЇ ЛІТЕРАТУРИ}

1. Про рішення Ради національної безпеки i оборони України від 20 травня 2016 року "Про стратегічний оборонний бюлетень України": Указ Президента України від 6 червня 2016 року № 240/2016 [Електронний ресурс]. - Режим доступу: zakon.rada.gov.ua/laws/show/n0006525-16

2. Про рішення Ради національної безпеки i оборони України від 4 березня 2016 року "Про Концепцію розвитку сектору безпеки і оборони України": Указ Президента України від 14 березня 2016 року № 92/2016 [Електронний pecypc]. - Режим доступу: zakon.rada.gov.ua/laws/show/92/2016

3. Про рішення РНБО України від 28 квітня 2014 року "Про заходи щодо підвищення ефективності планування в секторі безпеки i оборони: Указ Президента України від 13 травня 2014 р. № 468/2014 [Електронний ресурс]. Режим

zakon.rada.gov.ua/laws/show/468/2014
4. Review of force structures in implementation of partnership goal g 0028, preliminary report for consultations with NATO [Text] / Ministry of Defense . - Sofia, 28 May 2011. - 142 p.

5. Олевский В. Система планирования военного строительства НАТО / В. Олевский // Зарубеж. воен. обозрение. - М.: Изд. дом "Красная звезда", 2012. - № 12 (789). - С. 12-18.

6. Дєнежкін М.М. Стандарти НАТО та оборонне планування в Збройних Силах України / М. М. Дєнежкін, О.Л. Плахута // Зб. наук. пр. ЦНДІ ЗСУ. - К., - 2016. - № 3 (77), - інв. № 47408, - С. 121131.

7. North Atlantic treaty organization (NATO) / Nato Office of information and press. - Brussels., 2014. $536 \mathrm{p}$.

8. The Norwegian Navy under the 2017-2020 Long Term Defence Plan [Electronic resource]: http://www.navyrecognition.com/index.php/focusanalysis/naval-technology/4153-analysis-thenorwegian-navy-under-the-2017-2020-long-termdefence-plan.html.

9. Ingebrigtsen, Roger. 2012. Norwegian Experiences with Integrated Strategic Management. Panorama of global security environment 2011. Baratislava: Center for European and North Atlantic Affairs [Electronic resource]:

http://www.regjeringen.no/nb/dep/fd/aktuelt/taler_arti kler/politisk_ledelse/taler-og-artikler-av-statssekretarroger/2012/norwegian-experiences-with-integrated

10. French and German defence: The opportunities of transformation [Electronic resource]: http://www.irisfrance.org/wp-content/uploads/2015/03/IRIS-Notemarch-2015-IRIS-SWP.pdf.

11. Foreign Policy and Interdependence in Gaullist France [Electronic resource]: https://www.cso.nato.int/ACTIVITY_META.asp?AC $\mathrm{T}=1506$.

12. Poland's Defence Modernisation Plan: A Race Against Time [Electronic resource]: http://www.avascent.com/2016/09/polands-defencemodernisation-plan-race-time.

13. Poland and NATO: A Study in Civil-military Relations [Electronic resource]: https://cepa.ecms.pl/files/?id_plik=2343.

31. Romanian defence: Transformation of the Romanian Armed Forces[Electronic resource]: http://www.mapn.ro/publicatii/2013/defence.pdf.

14. The New Trends in Defence Planning and Their Impact on the Defence Planning Systems in Transitional Countries [Electronic resource]: http://www. odbrana.mod.gov.rs/odbranastari/vojni_casopisi/arhiva/ VDTransition.pdf.

15. The Danish Defence Agreement 2013-2017 [Electronic resource]: http://www.fmn. dk/eng/allabout/Documents/

TheDanishDefenceAgrement 2013-2017englishversion.

16. Netherlands Defence Doctrine - Ministerie van Defensie [Electronic resource]: https://www.defensie.nl/binaries/defensie/documenten /publicaties/2013/11/20/defence-doctrine-en/defensiedoctrine_en.pdf 
17. Slovakia : Centre for European and North Atlantic http://cenaa.org/analysis/slovakia.

Affairs - Analysis [Electronic resource]:

Стаття надійшла до редакції 04.07.2017

Денежкин Н. Н. к.воен.н.,с.н.с. ${ }^{1}$;

Наливайко А. Д. к.т.н., доцент ${ }^{2}$;

Поляєв А. I. ${ }^{2}$

1 - Центральный научно-исследовательский институт Вооруженных Сил Украины, Киев;

2 - Центр военно-стратегических исследований Национального университета обороны Украины имени Ивана Черняховского, Киев

\section{Особенности оборонного планирования в государствах-членах НАТО, на основе возможностей}

Резюме. В статье анализируются особенности организации и осуществления оборонного планирования на основе возможностей в государствах-членах НАТО. На основе этого анализа авторами предлагается свое видение путей совершенствования существующей системы оборонного планирования в Вооруженных Силах Украины и адаптации его к требованиям стандартов НАТО.

Ключевые слова: оборонное планирование, возможности, Вооруженные Силы, стандарты, НАТО.

N. Denezhkin, Ph.D, senior researcher ${ }^{1}$;

A. Nalivayko, Ph.D, assistant professor ${ }^{2}$;

A. Polyayev ${ }^{2}$

1 - Central Research Institute of the Armed Forces of Ukraine, Kyiv

2 - Center for Military and Strategic Studies of the National Defence University of Ukraine named after Ivan Chernyhovsky, Kyiv

Features of defense planning in NATO-member states, on the basis of capabilities

Resume. The article analyzes the peculiarities of organization and implementation of defense planning based on capabilities in NATO member states. On the basis of this analysis, the authors suggest their vision of the ways to improve the existing defense planning system in the Armed Forces of Ukraine and adapt it to the requirements of NATO standards.

Keywords: defense planning, capabilities, armed forces, standards, NATO. 